\title{
Perencanaan dan Evaluasi User Interface untuk Aplikasi Tunanetra Berbasis Mobile Menggunakan Metode User Center Design dan QUIM Evaluation
}

\author{
Arvin Claudy Frobenius ${ }^{\mathrm{a} 1}$ \\ ${ }^{a}$ Program Studi D3 Teknik Informatika, Universitas Amikom Yogyakarta \\ Jl. Padjajaran, Ring Road Utara, Kel. Condongcatur, Kec. Depok, Kab. Sleman, Prop. Daerah Istimewa Yogyakarta \\ larvinclaudyeamikom.ac.id
}

\begin{abstract}
Abstrak
Penyandangan tunanetra di identifikasikan sebagai seseorang yang memiliki keterbatasan dalam pengelihatan. Kesulitan dalam bernavigasi adalah salah satu permasalahan yang dihadapi oleh penyandang tunanetra disaat beraktifitas dalam sehari-hari salah satunya penggunaan smartphone. Pada perkembangan era teknologi saat ini, penggunaan smartphone sangat penting dimana smartphone memiliki manfaat yaitu dapat digunakan dan dibawa kapanpun dan dimanapun dengan mudah. Akan tetapi, tidak semua aplikasi mudah digunakan baik secara tampilan maupun pengalaman penggunaan untuk penyandang tunanetra, karena keterbatasan yang dimiliki oleh penyandang tunanetra, hal ini dikarenakan belum memperhatikan user interface dan user experience pengguna penyandang tunanetra. Salah satunya adalah aplikasi mobile Gablind, yaitu aplikasi berbasis Internet of Thing (IoT) yang terintegrasi dengan kacamata khusus untuk penyandang tunanetra, yang digunakan penyandang tunanetra bernavigasi ketika beraktifitas diluar. Pada tahap pengembangan a plikasi gablind memerlukan perencanaan baik dari segi user interface dan user experience, sehingga fitur-fitur dalam aplikasi dapat digunakan dengan baik oleh penyandang tunanetra. Pada penelitian ini berfokus pada pengguna, yaitu menerapkan metode user-centred-design (UCD) dan metode mengidentifikasi usability menggunakan faktor QUIM. Berdasarkan Analisis evaluasi dari penelitian ini, menghasilkan nilai rata-rata keseluruhan faktor QUIM dengan nilai $81,3 \%$ sehingga dikategorikan baik. Adapun faktor yang mendapatkan nilai $<=80 \%$ keatas adalah usefulness, universality, accessibility, trustfulness, dan learnability. Sedangkan terdapat juga faktor yang perlu diperbaiki karena nilai kurang dari 70\% yaitu productivity dan satisfaction.
\end{abstract}

Kata kunci: Tunanetra, User Interface, User Experience,Quality in Use Integrated Measurement (QUIM), Mobile.

\section{Design and Evaluation of User Interface for Mobile-Based Blind Application Using User Centre Design and QUIM Evaluation Methods}

\begin{abstract}
Blind people are identified as someone who has limited vision. Difficulty in navigation is one of the problems faced by blind people when doing daily activities, one of which is the use of smartphones. In the development of the current technological era, the use of smartphones is very important where smartphones have the benefit of being able to be used and carried easily anytime and anywhere. However, not all applications are easy to use both in appearance and experience for blind people, because of the limitations that blind people have, this is because they have not paid attention to the user interface and user experience of blind users. One of them is the Gablind mobile application, which is an Internet of Thing (IoT) based application that is integrated with special glasses for visually impaired persons, which are used by blind people to navigate when doing activities outside. At the development stage of the Gablind application, planning requires both the user interface and the user experience, so that the features in the application can be used properly by blind people. This research focuses on the user, namely applying the user-centred design (UCD) method and the method of identifying usability using the QUIM factor. Based on the evaluation analysis of this study, the overall average value of the QUIM factor is $81.3 \%$, so it is categorized as good. The factors that score $<=80 \%$ and above are usefulness, universality, accessibility, trustfulness, and learnability. Meanwhile, there are also factors that need to be improved because the value is less than $70 \%$, namely productivity and satisfaction.
\end{abstract}


Keywords: Visually Impaired, User Interface, User Experience, Quality in Use Integrated Measurement (QUIM), Mobile

\section{PENDAhUluan}

Penyandang tunanetra adalah seorang yang memiliki keterbatasan dalam penglihatan. permasalahan yang dihadapi penyandang tunanetra adalah bernavigasi dalam kegiatan sehari-hari. Berdasarkan data yang dilangsir oleh Badan Pusat Statistik (BPS), total penyandang tunanetra di Indonesia berjumlah 3.75 juta [1]. Keterbatasan yang dimiliki penyandang tunanetra terkadang membuat mereka memiliki rasa tidak kepercayaan diri, dan pesimis. Meskipun sudah ada alat bantu konvesional yang sudah digunakan oleh tunanetra, tetapi masih memiliki kekurangan. Oleh karena itu, diperlukan sebuah alat yang dapat melengkapi alat yang sudah ada, sehingga dapat membantu tunanetra dalam bernavigasi sempurna.

Di era modern saat ini, teknologi terus berkembang dan melahirkan inovasi-inovasi teknologi yang baru. Gablind adalah salah satu alat navigasi yang digunakan oleh tunanetra untuk membantu memberikan navigasi kepada tunanetra. Saat ini gablind dikembangkan berbasis IoT (internet of Thing) dengan mengkombinasikan hardware berupa kacamata khusus yang dapat mendeteksi sebuah halangan dan pengembangan software gablind berupa aplikasi berbasis mobile yang akan di integrasikan dengan kacamata khusus. Alasan penggunaan aplikasi berbasis mobile sendiri adalah mempermudah tunanetra membawa smartphone kemana-mana dan lebih praktis digunakan. Pengembangan aplikasi berbasis mobile harus juga dapat dipahami dan dipakai dengan mudah oleh pengguna aplikasi khususnya tunanetra.

Berdasarkan latar belakang permasalahan tersebut maka diperlukan adanya model user interface dan juga user experience yang interaktif sesuai dengan karakteristik pengguna tunanetra. Pada penelitian ini menggunakan metode User Centered Design (UCD), dimana sebuah filosofi perancangan yang menempatkan pengguna sebagai pusat dari sebuah proses pengembangan sistem [2]. Proses analisis usability menggunakan Standar Quality in Use Integrated Measurement (QUIM) yang berfungsi untuk menetapkan syarat kualitas dari sebuah produk. Terdapat 10 model penilaian dalam Quality in Use Integrated Measurement (QUIM) yaitu efficiency, Effectiveness, Productivity, Satisfaction, learnability, safety, trustfulness, accessibility, universality, dan usefulness [3].

Perancangan dan evaluasi ini dilakukan agar dapat menghasilkan model user interface dan user experience pada pengembangan aplikasi Gablind dari tahap lowfidelity, high-fidelity, hingga prototipe. Sehingga aplikasi berbasis mobile dapat digunakan oleh tunanetra dengan mudah dan mudah dipahami.

\section{TINJAUAN PUSTAKA}

\section{A. Tinjauan Pustaka}

Pada penelitian ini, melakukan analisis implementasi metode UCD dalam perancangan sistem pembelajaran bahasa ekspresif untuk digunakan terapis wicara terhadap penyandang sindrom asperger, setelah melakukan analisa dan implemetasi dihasilkan bahwa penggunaan metode
UCD digunakan dalam pembuatan user interface pada sistem pembelajaran bahasa efektif untuk penyandang sindrom asperger. Pada usability testing diperoleh dari proses dua kali proses pengujian. Pada pengujian pertama dihasilkan nilai rata-rata $75.6 \%$ dan pada pengujian kedua dihasilkan nilai dengan rata-rata 80.9 [4]. Selanjutnya terdapat penelitian melakukan analisis user interface media pembelajaran pengenalan kosakata untuk tunarungu menggunakan prinsip-prinsip metode UCD, dimana hasil dari perancangan model user interface berupa mockup dibangun menggunakan tools balsmiq mockup dan microsoft expression blend $4+$ sketchflow. Pada analisis pengujuan menggunakan metode Human Considerations in The Design of Business System yang terdiri dari pengetahuan pengguna dan pengalaman pengguna, karakteristik psikologi pengguna dan karakteristik fisik pengguna [5]. Pada penelitian selanjutnya melakukan perencanaan user interface game angklung dengan metode user centered design pada studi kasus saung angkling audio. Pada penelitian ini dihasilkan game berbasis mobile untuk game angklung yang berfokus kepada characteristic, task, environments dari pengguna. Pada analisis evaluasi usability, penelitian ini menggunakan metode QUIM. Pada hasil pengujian usabiliy menghasilkan nilai dengan presentase nilai terendah adalah $86 \%$ [6].

\section{B. Gablind}

Sistem utama Gablind dan Gablind App menggabungkan teknologi hardware dan software dimana Gablind sebagai perangkat keras berupa kaca mata yang dilengkapi dengan komponen elektronik sedangkan software membangun aplikasi berbasis Android. Aplikasi ini dikembangkan menggunakan sistem Android yang dapat terhubung dengan kacamata menggunakan konektivitas jaringan Bluetooth. Gambar berikut ini merupakan gambaran proses sistem yang terdapat di Gablind and Gablind App. Hal tersebut dapat dilihat pada gambar 1 [7].

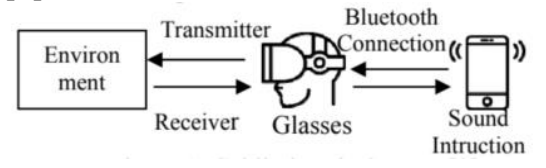

Gambar 1. Sistem Proses Gablind

Penggunaan aplikasi Gablind ini sebagai alat navigasi untuk penyandang tunanetra. Aplikasi ini dapat memberikan instruksi suara berupa bunyi "bip" kepada tunanetra. Semakin dekat "beeb" terdengar lebih cepat. Aplikasi ini akan aktif dan mulai mendeteksi rintangan jika dihubungkan dengan kacamata. Selain itu, aplikasi ini memiliki beberapa fitur yaitu pendeteksi lokasi kacamata dengan nama menu "where is my Gablind", untuk mengetahui lokasi penyandang tunanetra secara real time dengan nama menu G-location dan memberikan arahan bagi penyandang tunanetra ke suatu tempat yang dituju oleh penyandang tunanetra yang terintegrasi dengan google maps yaitu G-Walk. Alur sistem aplikasi dapat dilihat pada Gambar 2 [7]. 


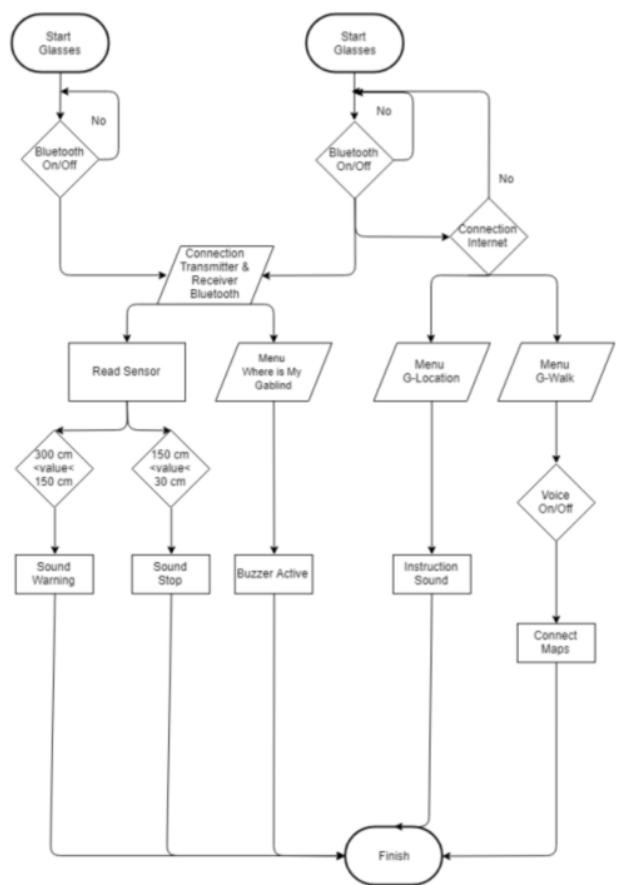

Gambar 2. Alur Sistem Aplikasi Gablind

\section{User Centered Design (UCD)}

User centered design adalah sebuah filosofi perancangan yang menempatkan user sebagai pusat dari sebuah proses pengembangan sistem [3]. Konsep dari UCD adalah user sebagai pusat dari proses pengembangan sistem, tujuan/sifat [8]. Dalam proses mendesain dengan menggunakan metode user centered design terdiri dari [9]:

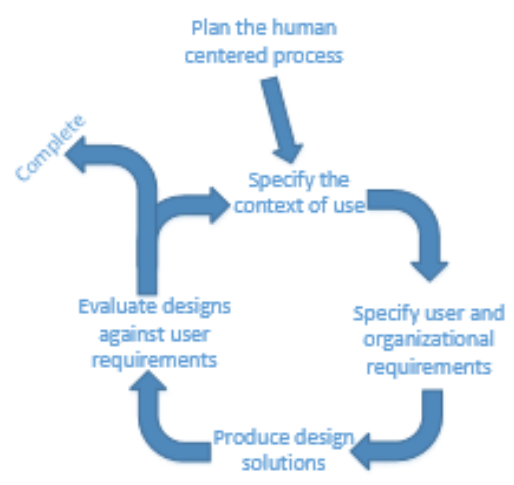

Gambar 3. Tahap User Centered Design Sumber: ISO 13409 (1999)

\begin{abstract}
1) Identifikasi: Orang-orang yang akan menggunakan produk, untuk apa mereka akan menggunakannya, dan dalam kondisi apa mereka akan menggunakannya sesuai dengan konteks pengguna. Data pengguna yang diperoleh dari tahap ini berupa sebuah persona pengguna yang meliputi karakteristik, kebiasaan, kebutuhan, dan motivasi dari pengguna.
\end{abstract}

2) Specify user requirements: Setelah pada tahap mengidentifikasi konteks pengguna, langkah selanjutnya adalah menentukan kebutuhan dari aplikasi untuk mengidentifikasikan kebutuhan pengguna. Hasil pada tahap ini berupa data kebutuhan pengguna dari aplikasi yang akan dibangun.

3) Produce design solution: Pada tahap ini melakukan proses perancangan design aplikasi sesuai kebutuhan pengguna setelah proses sebelumnya. Proses ini dilakukan beberapa proses yaitu mulai dari konsep kasar hingga desain lengkap. Hasil pada tahap ini adalah bentuk yang lebih detail dan implementasi dari sistem.

4) Evaluation against requirements: Tahap akhir adalah menguji perencanaan design sistem untuk menilai dan memastikan solusi design dapat sesuai dengan kebutuhan pengguna. Idealnya melalui pengujian kegunaan menggunakan pengguna aktual yang dituju sebagai kualitas pengujian untuk menghasilkan pengembangan software yang baik.

\section{User Experience}

User Experience Menurut definisi dari ISO 9241-210, user experience adalah persepsi seseorang dan responnya dari penggunaan sebuah produk, sistem, atau jasa. User Experiece (UX) menilai seberapa kepuasan dan kenyamanan seseorang terhadap sebuah produk, sistem, dan jasa. Sebuah prinsip dalam membangun User Experience adalah khalayak mempunyai kekuasaan dalam menentukan tingkat kepuasan sendiri (costumer rule) [10]. User experience merupakan kualitas pengalaman seseorang ketika berinteraksi dengan design tertentu [11].

\section{E. User Interface}

User interface adalah bagian dari komputer dan perangkat lunak yang dapat dilihat, didengar, disentuh, dan diajak bicara dengan proses pemahaman tertentu. user interface mempelajari perencanaan dan desain tentang bagaimana pengguna dan komputer dapat bekerja sama sehingga kebutuhan pengguna dapat terpenuhi dengan cara yang paling efektif [12].

\section{F. Quality in Use Integrated Measurement (QUIM)}

Quality in Use Integrated Measurement (QUIM) merupakan bentuk model yang digunakan untuk pengukuran usability. Tujuan utama dari QUIM adalah untuk menyediakan wadah dan kerangka kerja yang konsisten untuk faktor usability, kriteria dan metrik untuk tujuan pendidikan dan penelitian [3]. QUIM menguraikan metode untuk menetapkan, syarat mutu seperti mengidentifikasi, menganalisis, dan memvalidasi proses dan metrik kualitas suatu produk. Terdapat 10 faktor model dalam QUIM, yaitu [13]:

1) Efficiency: Merupakan kapabilitas suatu produk untuk pengguna dalam mengeluarkan sumber daya yang tepat.

2) Effectiveness: Merupakan kemampuan suatu produk dimana pengguna dapat menyelesaikan tugas-tugas yang dapat ditentukan dengan akurasi dan juga kelengkapannya.

3) Productivity: Merupakan tingkat efektifitas yang meliputi (upaya pengguna, waktu penyelesaian tugas, dan biaya pengunaan finansial). produktivitas menyangkut 
jumlah output bermanfaat yang diperoleh dari interaksi pengguna dengan produk perangkat lunak.

4) Satisfaction: Mengacu pada tanggapan subjektif dari pengguna tentang perasaan mereka saat menggunakan perangkat lunak (yaitu, apakah pengguna puas atau senang dengan sistem?).

5) Learnability: Kemampuan produk perangkat lunak untuk memungkinkan pengguna merasa bahwa mereka dapat secara produktif menggunakan produk perangkat lunak segera dan kemudian dengan cepat mempelajari fungsionalitas baru lainnya (bagi mereka).

6) Safety: Bagian dimana untuk memastikan suatu membatasi resiko membahayakan orang atau sumber informasi lainnya.

7) Trustfulness: Kepercayaan untuk pengguna bahwa produk yang digunakan memberikan manfaat dan fungsionalitas yang baik.

8) Accessibility: Kemampuan suatu produk perangkat lunak untuk digunakan oleh orang-orang dengan beberapa jenis kecacatan (mis., visual, pendengaran, psikomotor)

9) Universality: Menyangkut apakah produk perangkat lunak mengakomodasi keragaman pengguna dengan latar belakang budaya yang berbeda (misalnya, budaya lokal dipertimbangkan).

Produk perangkat lunak memungkinkan pengguna untuk memecahkan masalah nyata dengan cara yang dapat diterima. Kegunaan menyiratkan bahwa suatu produk perangkat lunak memiliki utilitas praktis, yang sebagian mencerminkan seberapa dekat produk tersebut mendukung model tugas pengguna sendiri.

\section{G. Pedoman Aksesbilitas}

Pada penelitian ini, menggunakan Pedoman Aksesibilitas Konten Web (WCAG) 2.0 dari W3C yang dikembangkan oleh beberapa universitas (MIT, ERCIM, dan Keio) yaitu menetapkan cara membuat konten Web lebih mudah diakses oleh para penyandang cacat. Aksesibilitas melibatkan berbagai cacat, termasuk penglihatan, pendengaran, fisik, ucapan, kognitif, bahasa, pembelajaran, dan cacat neurologis. Terdapat 4 prinsip pedoman aksesbilitas dalam menetapkan konten Web [14]:

1) Dapat dipahami (Perceivable) Komponen informasi dan antarmuka pengguna harus dapat ditampilkan kepada pengguna dengan cara yang dapat mereka rasakan. ada beberapa yang perlu diperhatikan yaitu menentukan alternative teks seperti cetakan besar, huruf braille, ucapan, simbol, atau bahasa yang lebih sederhana, menentukan alternatif untuk media berbasis waktu, Menentukan tata letak, dan menentukan pemisahan latar depan dan latar belakang.

2) Dioperasikan (Operable) Komponen antarmuka pengguna dan navigasi harus dapat dioperasikan. Ada yang perlu diperhatikan yaitu menyediakan waktu yang cukup untuk pengguna membaca dan menggunakan konten, menentukan cara untuk membantu pengguna menavigasi, dan menemukan konten.
3) Dapat dimengerti (understandable) Informasi dan pengoperasian antarmuka pengguna harus dapat dimengerti. Pada tahap ini adalah menentukan mereka berada dan menentukan inputan untuk membantu pengguna menghindari dan memperbaiki kesalahan

Kuat (Robust) Konten harus cukup kuat sehingga dapat diartikan secara andal oleh berbagai agen pengguna, termasuk teknologi bantuan. Pada tahap ini menentukan kompatibilitas dengan pengguna saat ini dan masa depan, termasuk teknologi bantu.

\section{METODOLOGI}

Pada penelitian Perencanaan Dan Evaluasi User Interface Untuk Aplikasi Tunanetra Menggunakan metode User Centered Design Dan QUIM Evaluation. Pendekatan yang digunakan adalah pendekatan kualitatif dan kuantitas. Data-data yang diperoleh merupakan hasil dari evaluasi usability menggunakan QUIM (Quality in Use Integrated Measurement) yang memiliki 10 faktor prinsip model. Pada Gambar 4 menggambarkan setiap tahap proses penyususnan penelitian ini. Berikut proses penelitian tersebut:

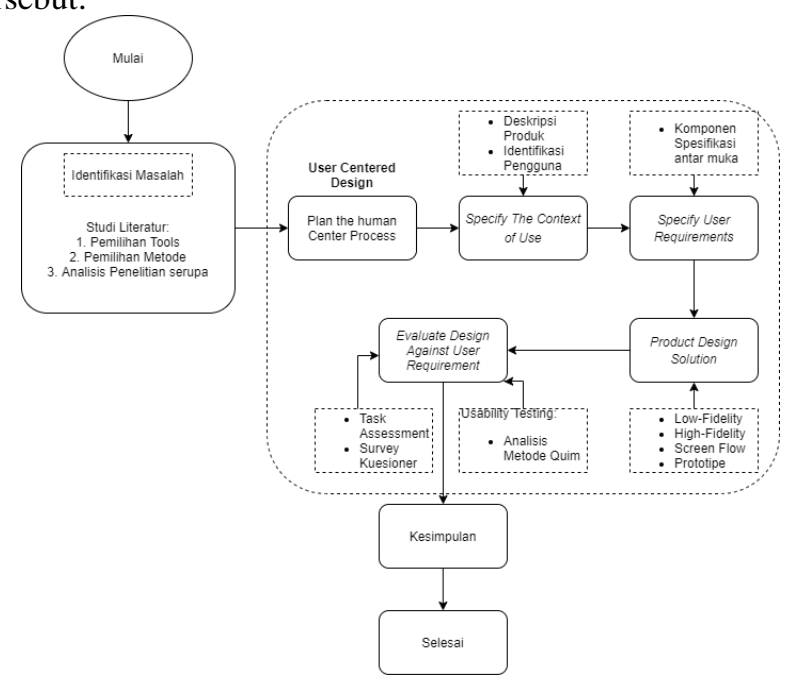

Gambar 4. Metodologi Penelitian

\section{A. Identifikasi Masalah}

Pada tahap ini, penelitian diawali dengan pengumpulan data dengan cara melakukan observasi, diskusi dan wawancara. Pada tahap ini selanjutnya akan dikumpulkan data tersebut dan dimasukkan dalam proses plan the human centered process.

\section{B. User Center Design}

\section{1) Plan the Human Centered Process}

Pengumpulan data dilakukan dengan wawancara dan observasi. Dalam observasi, diskusi dan wawancara digunakan untuk mengetahui aktifitas tunanetra, kebiasaan tunanetra, cara tunanetra berkomunikasi, cara tunanertra bernavigasi. Selain itu penelitian ini melakukan studi literatur yaitu mencari penelitian yang sama dan juga mencari konsep dan metode dalam membuat desain untuk accessibility. Sehingga dari data dari identifikasi masalah dapat diolah sesuai kebutuhan design user interface dan experience tunanetra. 


\section{2) Specify the Context of Use}

Pada tahap ini merupakan tahap proses identifikas pengguna yaitu membuat user persona dimana pengguna yang akan memakai sistem yang akan dibuat. Metode dalam pengumpulan data user persona dapat dilakukan dengan cara wawancara dan observasi langsung dengan pengguna.

\section{3) Specify User Requirements}

Merupakan penjelasan tentang kebutuhan pengguna terhadap aplikasi dan kemampuan aplikasi untuk memenuhi kebutuhan dari pengguna. Kebutuhan dapat dilihat dari pembelajaran dan penguasaan tentang smartphone, menentukan guideline aksesbilitas untuk tunanetra, membuat scenario model user experience pada aplikasi gablind, dan membuat model konseptual design aplikasi gablind.

\section{4) Produce design solution}

Pada tahap ini adalah alur proses pembuatan design Gablind yaitu melalui wireframe-low fidelity, wireframehigh fidelity, visual desain dan code. Seperti gambar 5.

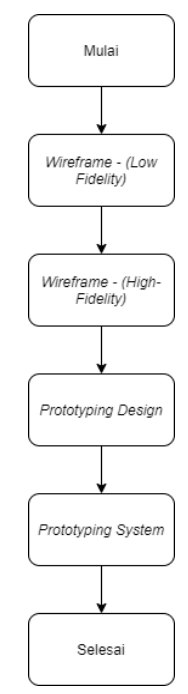

Gambar 5. Produce Design Solution

\section{5) Evaluation against requirements}

Pada tahap evaluasi ini dilakukan untuk mengetahui hasil dari prototype yang sudah dibuat apakah sudah sesuai dengan kebutuhan pengguna yang didapat dari Specify the Context of Use, Specify User Requirements dan juga dilihat dari validasi untuk memastikan ketepatan dan keakuratan data yang dihasilkan. Evaluasi dilakukan dengan menggunakan prototype yang sudah dibuat kepada tunanetra. Selain menggunakan prototype juga menggukan kuisoner dalam pengambilan data yaitu dengan membantu membacakannya. Kuisoner yang digunakan adalah kuisoner tertutup dengan pilihan "ya" dan "tidak". Jika dalam hasil yang diperoleh dari prototype dan kuisoner tidak valid maka kembali ketahap identifikasi pengguna untuk melakukan evaluasi dalam mengidetifikasi pengguna dan memastikan kembali kebutuhan pengguna sesuai dengan konsep user centered design. Jika hasil dari prototype dan kuisoner adalah valid akan dilakukan proses pengelolahan data.

\section{Mengidentifikasi Tugas (Task)}

Pada tahap ini pengguna aplikasi akan diberikan tugas dan tujuan pada aplikasi gablind. Data ini didapatkan dengan melakukan uji validasi kepada pengguna yaitu apa saja yang dapat dilakukan pengguna pada sistem. Pada akhirnya pengguna dapat menyelesaiakan tujuan yang diinginkan pada sistem.

Pada tahap mengidentifikasi tugas, terdapat 5 tugas yang harus dilakukan oleh pengguna (tunanetra). Setiap tugas yang diberikan memiliki fungsi masing-masing. Pada menu where's my gablind digunakan untu mengetahui lokasi kacamata yang ditandai dengan suaran pada kacamata, pada menu g-location digunakan untuk mengetahi posisi pengguna (tunanetra) dengan cara intruksi suaran yang diinfokan melalui aplikasi, dan pada menu g-walk digunakan untuk memberikan petunjuk arah jalan kemana penggnuan (tunanetra) ingin pergi.

TABEL I

IDENTIFIKASI TUGAS (TASK)

\begin{tabular}{|l|l|}
\hline No & \multicolumn{1}{|c|}{ Tugas } \\
\hline 1 & $\begin{array}{l}\text { Melakukan koneksi antara } \\
\text { smartphone dan kacamata }\end{array}$ \\
\hline 2 & Masuk menu where's my gablind \\
\hline 3 & Masuk menu g-location \\
\hline 4 & Masuk menu g-walk \\
\hline 5 & Melakukan inputan suara \\
\hline
\end{tabular}

\section{Wawancara}

Wawancara adalah bentuk komunikasi lisan dan bertatap muka antara orang-orang yang berkepentingan dengan objek penelitian untuk tujuan tertentu. Sebelum melakukan wawancara, melakukan tahap pembuatan kuisoner dimana pada penelitian ini menggunakan metode QUIM (Quality in Use Integrated Measurement). 10 faktor pada metode QUIM diuraikan menjadi kreteria, faktor dan metik. Faktor dan kreteria saling berhubungan dalam pengujian. Selanjutnya kreteria yang dibuat akan dijadikan landasan untuk membuat pertanyaan pada wawancara/kuisoner untuk pengujian.

TABEL III

KRETERIA DAN FAKTOR QUIM [15]

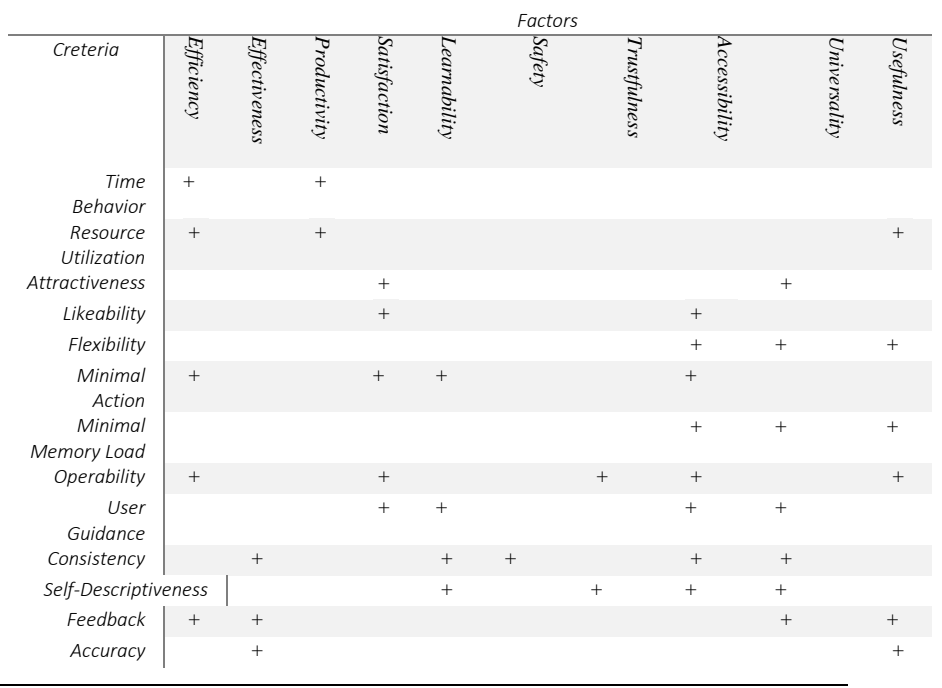




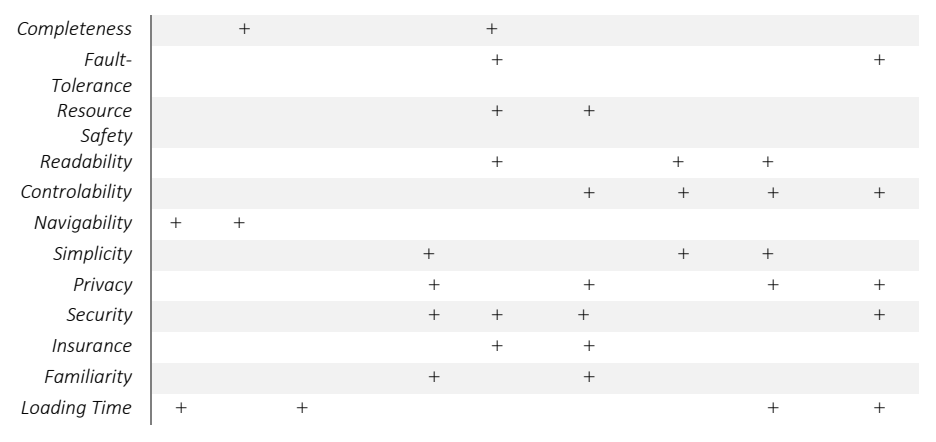

Seperti yang dijelaskan pada evaluation against requirements terdapat wawancara tertutup dimana pengguna hanya menjawab "iya" dan "tidak". Perhitungan wawancara dilakukan dalam bentuk table dan dipersatukan per-faktor. Nilai setiap faktor yang diberikan 1 dan 0.

Setelah dilakukan pembobotan nilai, kemudian data akan dihitung rata-ratanya pada setiap faktor, berikut rumus rata-rata [16]:

$$
\bar{x}=\frac{1}{n}\left(x_{1}+x_{2}+x_{3}+\cdots+x_{n}\right)
$$

$\bar{x}=$ rata - rata hitung

$x_{i}=$ Nilai Sampel $k e-i$

$n=$ Jumlah sample

TABEL IIIII

Pembobotan KATEGORI PENILAIAN

\begin{tabular}{|l|l|}
\hline \multicolumn{1}{|c|}{ Nilai } & \multicolumn{1}{c|}{ Kategori } \\
\hline $91-100$ & Sangat Baik \\
\hline $81-90$ & Baik \\
\hline $71-80$ & Cukup \\
\hline $61-70$ & Kurang \\
\hline $51-60$ & Sangat Kurang \\
\hline
\end{tabular}

\section{HASIL DAN PEMBAHASAN}

\section{A. Perencanaan Antar Muka}

Pada tahap perencanaan melalui beberapa tahap yaitu wireframe-low fidelity, wireframe-high fidelity, visual desain (prototype) dan code. Pada pembuatan wireframe low dan high fidelity menggunakan aplikasi adobe XD dan untuk menjalankan prototype menggunakan Invision App.

\section{1) Wireframe-low fidelity}

Berikut adalah wifeframe-low fidelity. Pada tahap ini lebih berfokus pada elemen dasar seperti tombol, navigasi dan text. Pembuatan wireframe-low fidelity menggunakan aplikasi Adobe XD. Terdapat 5 screen yang dibuat. Seperti pada gambar 6, gambar 7 dan gambar 8 .

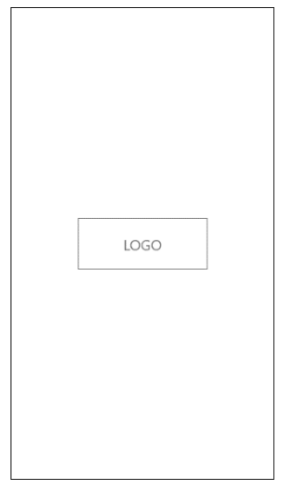

Gambar 6. Wireframe-low fidelity Splash Screen

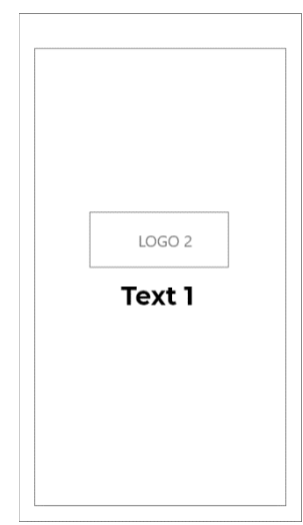

Gambar 7. Wireframe-low fidelity Koneksi Bluetooth

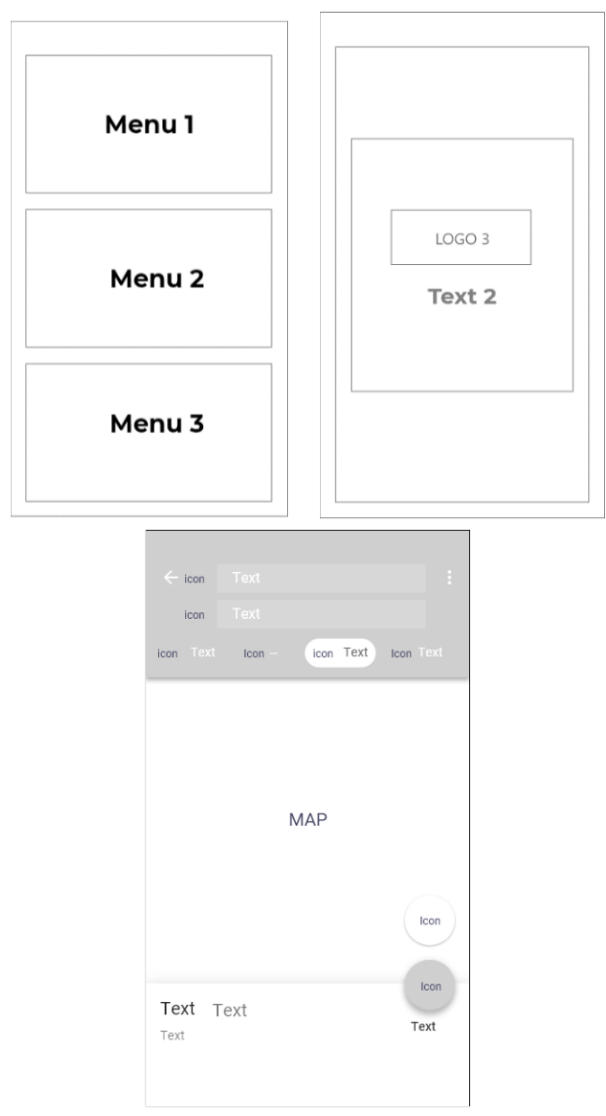

Gambar 8. Menu Utama Pada Gablind 


\section{2) Wireframe-high fidelity}

Pada tahap wirefrme-high merupakan desain jadi dari aplikasi yang akan dibuat. Pada wireframe-high fidelity merupakan versi detail dari wireframe-low fidelity. Detail-detail yang ditambahakan berupa icon, warna dan lainnya. Seperti pada gambar 9.

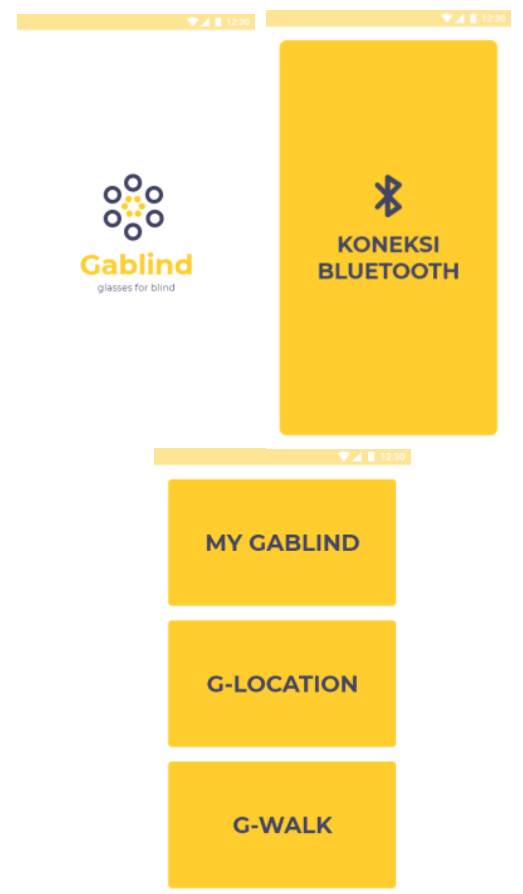

Gambar 9. Wireframe-high fidelity

\section{3) Visual Desain (Prototipe)}

Pada tahap ini adalah kelanjutan dari tahap wireframehish fidelity, dimana dari high fidelity akan dibuat prototype desain. Pada tahap prototype ini menggunakan aplikasi Invision App. Hasil seperti gambar 10.

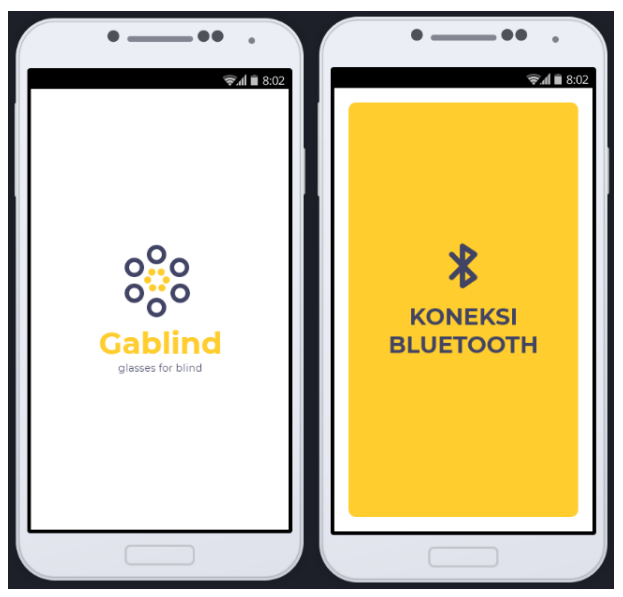

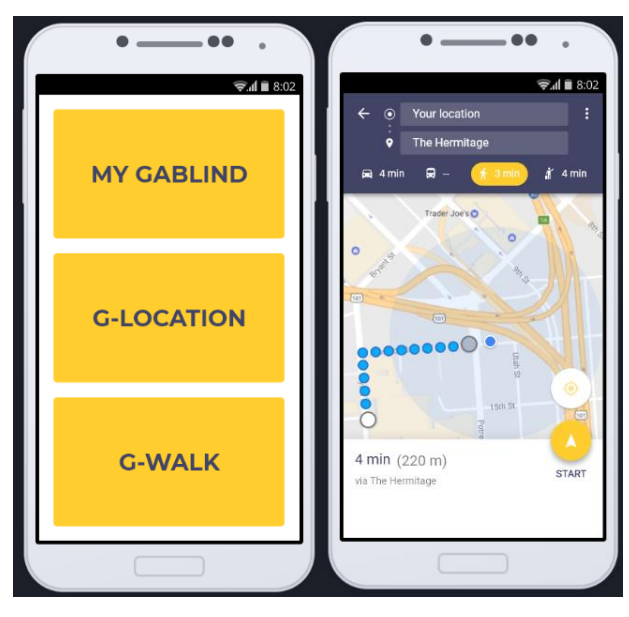

Gambar 10. Visual Desain (Prototipe)

\section{4) Screen Flow}

Berikut ada sceen flow dimana alur sistem bekerja di setiap screen. Dimana ketika aplikasi gablind terpilih akan masuk pada screen splash dan masuk kedalam menu Bluetooth, pada menu ini smartphone harus dikoneksikan dengan kacamata khusus gablind. Setelah aplikasi sudah terkoneksi dengan kacamata khusus gablind akan masuk ke dalam menu utama yaitu terdapat menu "My Gablind" digunakan untuk mengetahui lokasi kacamata khusus gablind, "G-Location" digunakan untuk mengetahui lokasi tunanetra, "G-Walk" digunakan untuk memberikan arah lokasi tempat yang diinginkan tunanetra dan terintegrasi dengan google map. Gambar screen flow seperti pada gambar 11 .

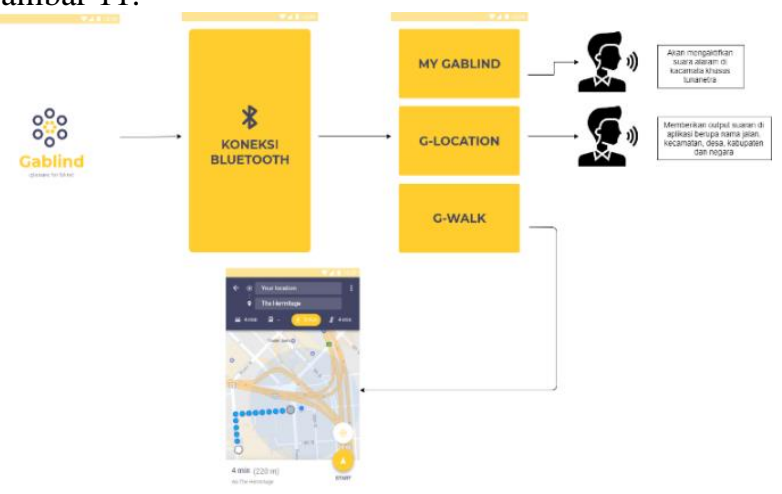

Gambar 11. Screen Flow

\section{B. Pengujian dan Analisis}

Pada tahap ujian dan analysis pada desain user interface dan user experience untuk aplikasi gablind yang digunakan oleh tunanetra adalah menggunakan pengujian dan analisis Quality in Use Integrated Measurement (QUIM). Berikut hasil analisis dan pengujian pada tabel 4.

TABEL IVV

HASIL PENGUJIAN DAN ANALISIS QUIM

\begin{tabular}{|c|l|c|c|}
\hline No & Faktor & Presentase & Kategori \\
\hline 1 & Efficiency & 75 & Cukup \\
\hline 2 & Effectiveness & 72 & Cukup \\
\hline 3 & Satisfaction & 64 & Kurang \\
\hline 4 & Productivity & 69 & Kurang \\
\hline 5 & Learnability & 92 & Sangat Baik \\
\hline
\end{tabular}




\begin{tabular}{|c|l|c|c|}
\hline 6 & Safety & 80 & Cukup \\
\hline 7 & Trustfulness & 88 & Baik \\
\hline 8 & Accessibility & 96 & Sangat Baik \\
\hline 9 & Universality & 87 & Baik \\
\hline 10 & Usefulness & 95 & Sangat Baik \\
\hline \multicolumn{2}{|l}{ Rata-Rata } & 81,3 & Baik \\
\hline
\end{tabular}

Berdasarkan data yang telah diolah dapat dilihat bahwa rata-rata dari semua faktor QUIM adalah 81.3 persen yang memiliki kategori sangat baik dan faktor yang memiliki nilai yang besar adalah faktor accessibility dengan nilai 96 persen. Maka dari data ini dapat dikatakan bahwa perencanaan prototype aplikasi gablind yang digunakan untuk tunanetra telah sesuai dengan user persona untuk tunanetra dengan rentan usia 12-30 tahun yang sudah pernah dan sudah mengerti tentang penggunaan smartphone. Berikut analisis dari data hasil pengolahan data pengujian.

1) Efficiency: Pada faktor efficiency mendapatkan ratarata nilai 75 persen. Pada faktor ini berfokus pada penggunaan dan pengetahuan aplikasi. Dari data menunjukan bahwa ada beberapa pengguna aplikasi baik tunanetra penglihatan rendah dan tunanetra penglihatan buta total setelah melakukan uji coba, tidak semua memahami dan menggunakan teknologi dan perlu bimbingan dari orang tua atau pendamping dalam memberikan pengetahuan tentang teknologi.

2) Effectiveness: Pada faktor effectiveness didapatkan nilai rata-rata 72 persen. Pada faktor ini berfokus pada tugas-tugas(tasks) yang dilakukan oleh pengguna. Dari data menunjukan bahwa pengguna terdapat tugas (task) yang sesuai dan mudah dipahami, namun juga terdapat pengguna masih memiliki nilai effectiveness masih rendah terhadap suatu task.

3) Satisfaction: Pada faktor ketiga satisfaction didapatkan nilai rata-rata yang kurang baik yaitu 64 persen. Pada faktor ini berfokus pada kepuasan dalam penggunaan aplikasi. Kurang kepuasan adalah dalam penggunaan intruksi suara menggunakan Bahasa Inggris dan tidak semua pengguna mengerti dalam pemakaian Bahasa Inggris. Sehingga harus menggunakan Bahasa yang sesuai kebutuhan pengguna.

4) Productivity: Pada faktor keempat productivity mendapatkan nilai 69 persen. Pada faktor ini berfokus pada konten fitur yang akan digunakan oleh pengguna. Pada hasil data yang diperoleh adalah konten fungsi setiap menu sudah baik karena sudah sesuai dengan kebutuhan pengguna dan masih memiliki kekurangan yaitu kamampuan pengguna dalam memahami fitur dan intruksi.

5) Learnability: Pada faktor kelima learnability mendapatkan nilai 92 persen. Pada faktor ini berfokus pada bagaimana pengguna dapat mempelajari setiap menu dan cara menjalankan setiap konten yang terdapat pada aplikasi. Dari hasil data menunjukan bahwa pengguna dapat mempelajari, menggunakan dan menghafal setiap menu dan fitur dalam dua kali uji coba.

6) Safety: Pada faktor keenam safety mendapatkan nilai 80 persen. Pada faktor ini berfokus pada bagaimana aplikasi dapat memberikan balasan yang cepat pada pengguna, ketika pengguna melakukan kesalahan. Pada uji coba yang dilakukan pengguna dapat mengatasi masalah yang dihadapi dan dapat mengatasi kesalahan dengan baik dengan balasan yang baik ke pengguna.

7) Trustfulness: Pada faktor ketujuh trustfulness mendapatkan nilai 88 persen. Pada faktor ini berfokus pada penilaian pengguna terhadap aplikasi dari kebermanfaatan dan fungsionalitas. Dari hasil uji coba menunjukan pengguna menilai bahwa untuk manfaat dan fungsionalitas sudah sesuai dengan kebutuhan dimana aplikasi gablind dapat terintegrasi dengan kacamata khusus gablind dan memberikan arahan navigasi untuk pengguna.

8) Accessibility: Pada faktor kedelapan accessibility mendapatkan nilai 96 persen. Pada faktor ini berfokus pada konten dan kemudahan intruksi yang diberikan. Dari hasil uji coba yang dilakukan pengguna dapat memahami konten, letak kontek dan intruksi yang diberikan dengan baik.

9) Universality: Pada faktor kesembilan universality mendapatkan nilai 87 persen. Pada faktor ini berfokus pada kebiasaan pengguna dalam menggunakan aplikasi gablind. Pada hasil uji coba pengguna dapat menggunakan aplikasi dengan lancer dan mudah mengingat letak-letak setiap menu.

10) Usefulness: Pada faktor kesepuluh usefulness mendapatkan nilai 95 persen. Pada faktor ini pada konten dan fungsi pada setiap menu. Dihasilkan konten disajikan sesuai dengan pengguna dan memberikan feedback berupa intruksi suara sehingga pengguna mengetahui apa yang di lakukan disetiap aktifitas smartphone.

\section{KESIMPULAN}

Berdasarkan perencanaan, analisis dan pengujian aplikasi mobile yang digunakan untuk pengguna tunanetra menggunakan metode analisis Quality in Use Integrated Measurement (QUIM) menghasilkan kesimpulan yaitu:

1) Tingkat hasil pengujian aplikasi menggunakan metode Quality in Use Integrated Measurement (QUIM) menghasilkan nilai keseluruhan faktor dengan pembobotan kategori nilai baik, yaitu dengan rata-rata 81,3 persen.

2) Berdasarkan uji coba dalam usability testing menggunakan metode QUIM, Perencanaan aplikasi gablind ini dapat direkomendasikan untuk penggunaan aplikasi berbasis mobile tunanetra

Adapun saran pada penelitian ini untuk dapat dikembangkan pada penelitian selanjutnya adalah sebagai berikut:

1) Pada faktor effectiveness dan efficiency perlu di tingkatkan yaitu memberikan intruksi suara dengan Bahasa yang bisa di ubah-ubah sesuai kebutuhan pengguna, dan harus memberikan pengenalan lebih untuk mengerti tentang aplikasi mobile dan penggunaan melalui tutorial. 
2) Pada penelitian selanjutnya perlu adanya peningkatan pada faktor productivity dan satisfacation karena memiliki nilai kurang pada hasil evaluasi menggunakkan metode QUIM.

\section{DAFTAR PUSTAKA}

[1] A. C. Frobenius dan E. R. H. Saputra, "kacamata berbasis maxsonar terintegrasi dengan aplikasi mobile android untuk memberikan navigasi tunanetra menggunakan jaringan bluetooth," Seminar Nasional Teknologi Informasi dan Multimedia, no. ISSN: 2302-3805, pp. 1-6, 2018.

[2] I. Purnama, "Perancangan Kamus Muslim Berbasis Smartphone Android Dengan Metode User Centered Design (UCD)," Jurnal Ilmiah AMIK Labuhan Batu, vol. 5, no. 3, pp. 1-14, 2017.

[3] L. L. Shidqi, V. Effendy dan A. Herdiani, "Model User Interface Aplikasi Pembelajaran Doa-doa Harian Sesuai User experince Anak Usia Dini Menggnakan Metode User Centered Design," $e$ Proceeding of Engineering, vol. 4, no. 3, pp. 4866-4873, 2017.

[4] Z. Mukhtar, A.Herdiani dan E. R. Kaburuan, "Analisis Impementasi Metode UCD Dalam Perancangan Sistem Pembelajaran Bahasa Ekspresif Untuk Digunakan Terapis Wicara Terhadap Penyandang Sindrom Asperger", e-Proceeding of Engineering, Vol. 6, No.2, pp 8488-8497, 2019.

[5] A.M.B. Jelita Ardhiyani,"Analisis User Interface Media Pembelajaran Kosakata Untuk Tunarungu”, Jurnal Ilmiah Komputer dan Informatika (KOMPUTA), No. ISSN: 2089-8497, 2019.

[6] W. K. Hartanto, D. Junaedi dan E. R. Kaburunan,’Perencanaan User Interface Game Angklung Dengan Metode User Centered Design (Studi Kasus Saung Angklung Udjo)", Ind. Journal on Computing, vol.4, no. 1, pp. 85-92, 2019.

[7] A. C. Frobenius, E. Utami and A. Nasiri, "Analysis of Speed Gablind App in Detecting Obstacle-Experiment Results," 2018 3rd International Conference on Information Technology, Information System and Electrical Engineering (ICITISEE), Yogyakarta, Indonesia, pp. 319-324, doi:10.1109/ICITISEE.2018.8720964, 2018.

[8] A. Amborowati, "Rancangan Sistem Pameran Online menggunakan Metode UCD ( User Centered Design )," Jurna Dasi, 2010.

[9] J. J. Garrett, The Elements of User Experience: User-Centered Design for the Web and Beyond,, United States of America, 2011

[10] B. W. Mendiola, "User Experience (UX) Sebagai Bagian Dari Pemikiran Desain Dalam Pendidikan Tinggi Desain komunikasi Visual", HUMANIORA, vol. 2, no. 2, pp. 1158-1166, 2011

[11] D. Darmawan, Inovasi Pendidikan, Bandung: PT. Remaja Rosdakarya Offset, 2012.

[12] A. M. B. Jelita Ardhiyani, "Analisis User Interface Media Pembelajaran Pengenalan Kosakata Untuk Anak Tunarungu", Jurnal Ilmiah Komputer dan Informatika (KOMPUTA), no. ISSN: 2089-9033 , pp. 45-54, 2014.

[13] V. E. S. M. D. D. J. S. M. Setyo Dwi Utomo, "Analisis dan Implementasi User Interface Aplikasi Pengenalan Hewan Sebagai Media Interaktif Pembelajaran Untuk Pendidikan Anak Usia Dini Dengan Teknologi Augmented Reality Menggunakan Metode Child Centered Design," e-Proceeding of Engineering , vol. 4, no. 3, pp. 4892- 4899, 2017.

[14] MIT, ERCIM dan KEIO, "w3.org," W3C, 1112 2008. [Online]. Available: https://www.w3.org/TR/WCAG20/\#intro. [Diakses 15 $112019]$.

[15] A. Seffah, M. Donyaee, B. R. Kline, H. K. Padda, "Usability Measurement and Metrics: A Consolidated Model", Software Qual J, pp. 159-178, 2006.

[16] P. D. d. S. Pendidikan-Kebudayaan, "Pengantar Statistik," Setjen, Kemdikbud, Jakarta, 2014 